\title{
KEEFEKTIFAN MEDIA KOMIK TERHADAP KEMAMPUAN MEMBACA PEMAHAMAN PADA SISWA KELAS IV SD
}

\author{
Mei Fita Asri Untari1 \& Aprilianta Adi Saputra²
}

\author{
1,2PGSD Universitas PGRI Semarang \\ 1,2 Jalan Sidodadi Timur no 24 Semarang \\ 'Email: mei_fita@ymail.com \\ 2Email: aprilianta@ymail.com
}

\begin{tabular}{|c|c|}
\hline ABSTRACT & ABSTRAK \\
\hline $\begin{array}{l}\text { This research is motivated by the low reading } \\
\text { interest of children who have an impact on } \\
\text { learning outcomes is low and the need to } \\
\text { streamline the reading comprehension to be } \\
\text { able to easily understand the material being } \\
\text { studied. This study aims to determine the } \\
\text { effectiveness of the medium of comics to the } \\
\text { students' reading ability. Based on the analysis of } \\
\text { data, the first measurement using the story } \\
\text { "Reaching Cita Although almost Despair" of } 30 \\
\text { fourth grade students of SDN 03 Bergaskidul } \\
\text { Semarang District } 25 \text { students with learning } \\
\text { outcomes is high enough - and } 5 \text { students with } \\
\text { poor outcomes. The average was } 73.33 \text {. After } \\
\text { being treated for the provision of comics, from } 30 \\
\text { students of SDN 03 Bergaskidul Semarang } \\
\text { regency. Retrieved } 29 \text { students achieving grades } \\
\text { with the criteria fairly high and only one student is } \\
\text { still berkriteria low. The average value rose to } \\
81.33 \text {. Percentage increase is } 3.878 \% \text {. The second } \\
\text { measurement using the story "Cita-citaku" of } 30 \\
\text { fourth grade students of SDN 03 Bergaskidul } \\
\text { Semarang District there are } 14 \text { students with } \\
\text { learning outcomes is high enough - and } 16 \\
\text { students with poor outcomes. The average was } \\
53.67 \text {. After being treated for the provision of } \\
\text { comics, from } 30 \text { students of SDN 03 Bergaskidul } \\
\text { Semarang regency. Retrieved } 22 \text { students } \\
\text { achieving grades with the criteria fairly high and } \\
8 \text { students who are still berkriteria low. The } \\
\text { average value rose to } 66.67 \text {. Percentage } \\
\text { increase is } 2,037 \% \text {. }\end{array}$ & $\begin{array}{l}\text { Penelitian ini dilatarbelakangi oleh rendahnya } \\
\text { minat membaca anak yang berdampak pada } \\
\text { hasil belajar yang rendah dan perlunya } \\
\text { mengefektifkan kemampuan membaca } \\
\text { pemahaman agar dapat memahami dengan } \\
\text { mudah materi yang dipelajari. Penelitian ini } \\
\text { bertujuan untuk mengetahui keefektifan media } \\
\text { komik terhadap kemampuan membaca siswa. } \\
\text { Berdasarkan analisis data, pengukuran pertama } \\
\text { menggunakan cerita "Meraih Cita Walau Nyaris } \\
\text { Putus Asa" dari } 30 \text { siswa kelas IV SDN Bergaskidul } \\
\text { O3 Kabupaten Semarang terdapat } 25 \text { siswa } \\
\text { dengan kriteria hasil belajar cukup tinggi dan } 5 \\
\text { siswa dengan kriteria hasil rendah. Rata-ratanya } \\
\text { adalah 73,33. Setelah diberi perlakuan berupa } \\
\text { pemberian komik, dari } 30 \text { siswa SDN Bergaskidul } \\
\text { 03 Kabupaten Semarang. Diperoleh } 29 \text { siswa } \\
\text { mencapai nilai dengan kriteria cukup-tinggi dan } \\
\text { hanya } 1 \text { siswa yang masih berkriteria rendah. } \\
\text { Rata-rata nilainya naik menjadi } 81,33 \text {. Persentase } \\
\text { kenaikannya adalah 3,878\%. Pengukuran kedua } \\
\text { menggunakan cerita "Cita-citaku" dari } 30 \text { siswa } \\
\text { kelas IV SDN Bergaskidul 03 Kabupaten } \\
\text { Semarang terdapat } 14 \text { siswa dengan kriteria hasil } \\
\text { belajar cukup tinggi dan } 16 \text { siswa dengan kriteria } \\
\text { hasil rendah. Rata-ratanya adalah } 53,67 \text {. Setelah } \\
\text { diberi perlakuan berupa pemberian komik, dari } \\
30 \text { siswa SDN Bergaskidul 03 Kabupaten } \\
\text { Semarang. Diperoleh } 22 \text { siswa mencapai nilai } \\
\text { dengan kriteria cukup tinggi dan } 8 \text { siswa yang } \\
\text { masih berkriteria rendah. Rata-rata nilainya naik } \\
\text { menjadi 66,67. Persentase kenaikannya adalah } \\
2.037 \% \text { Kata kunci: kefektifan, media komik, membaca } \\
\text { pemahaman. }\end{array}$ \\
\hline
\end{tabular}

How to Cite: Untari, M., \& Saputra, A. (2016). KEEFEKTIFAN MEDIA KOMIK TERHADAP KEMAMPUAN MEMBACA PEMAHAMAN PADA SISWA KELAS IV SD. Mimbar Sekolah Dasar, 3(1), 29-39. doi:http://dx.doi.org/10.17509/mimbarsd.v3i1.2354.

\section{PENDAHULUAN Dalam Undang-Undang}

Republik Indonesia Nomor 20 Tahun 2003 pendidikan nasional adalah pendidikan yang berdasarkan Pancasila dan Undang-
Undang Dasar 1945 yang berdasarkan pasal 1 ayat 2, diterangkan bahwa 
Mei Fita Asri Untari \& Aprilianta Adi Saputra, Keefektifan Media Komik...

pada nilai-niai agama, kebudayaan, nasional Indonesia dan tanggap terhadap perubahan zaman. Pendidikan merupakan bekal untuk semua orang dalam menjalani kehidupan mereka. Pendidikan tidak hanya bisa dilakukan di dalam sekolah saja, tetapi juga dapat dilakukan di mana saja, kapan saja dan oleh siapa saja. Pendidikan sangatlah penting bagi manusia. Bisa dibayangkan jika manusia samasekali tidak berpendidikan karena dalam pendidikan tidak hanya soal materi-materi dalam sekolah saja akan tetapi hal-hal yang kita butuhkan dalam bersosialisasi, bermasyarakat, menghargai orang lain dan lain-lain. Dengan adanya pendidikan, manusia diharapkan selalu dapat beradaptasi dengan perkembangan zaman. Zaman yang selalu berubah menuntut manusia untuk mampu berpikir kritis terhadap perubahan-perubahan yang ada di lingkungan sekitar. Seperti halnya dunia pendidikan yang selalu berubah dan selalu berkembang.

Perkembangan dalam pendidikan terlihat dalam kurikulum yang selalu diperbarui sesuai dengan kebutuhan para siswa. Pendidikan di Indonesia sekarang ini menggunakan kurikulum yang terbaru yaitu Kurikulum 2013, dan sudah diterapkan di sekolah-sekolah, baik di SD, SMP, maupun SMA, tetapi hanya beberapa saja yang sudah menerapkan. Berdasarkan perkembangan informasi terbaru, diketahui terdapat sekitar 30\% sekolah di Indonesia yang sudah menerapkannya. Kurikulum 2013 menekankan pada peran siswa sebagai pusat pembelajaran. Dengan menuntut siswa untuk lebih aktif, kreatif, produktif dan mempunyai jiwa kebangsaan, maka mata pelajarannya dijadikan terintegrasi dengan susunan tema demi tema yang setiap kompetensinya merupakan gabungan dari beberapa mata pelajaran. Dengan demikian, diharapkan siswa lebih mudah untuk mengingat atau bahkan memahami pelajaran.

Dalam mengikuti perkembangan zaman yang selalu berubah, maka manusia haruslah selalu belajar. Kata belajar erat kaitannya dengan dunia sekolah. Slameto (2010, p. 2) mengemukakan bahwa belajar adalah suatu proses usaha yang dilakukan seseorang untuk memperoleh suatu perubahan tingkah laku yang baru secara keseluruhan, sebagai hasil pengalamannya sendiri dalam interaksi dengan lingkungannya. Sama halnya dengan pendidikan, belajar juga dapat dilakukan di mana saja, kapan saja dan oleh siapa saja. Sekarang ini, belajar lebih dikaitkan dengan sekolah. Siswa ketika bersekolah juga harus belajar, namun tidak sedikit siswa yang belajar hanya sekadar belajar. Mereka belajar tanpa memahami apa yang mereka pelajari. Contohnya ketika pelajaran IPA dengan materi jenis-jenis hewan berdasarkan makanannya. Para siswa hanya menghafal jenis-jenis hewan tersebut seperti karnivora, herbivora, dan omnivora. Mereka tidak memahami ciri-ciri hewan 
tersebut, namun hanya menghafal kalau herbivora itu pemakan tumbuhan, karnivora itu pemakan daging dan omnivora itu pemakan segalanya. Hal seperti itu terjadi, dapat disinyalir karena dua penyebabnya, yaitu siswa memang sulit untuk memahami materi tersebut, atau bisa jadi siswa sendiri yang kurang berminat dalam memahami materi.

Masalah-masalah di atas ditemukan pada siswa kelas IV SD Negeri Bergaskidul 03. SD Negeri Bergaskidul 03 merupakan salah satu sekolah di Kabupaten Semarang yang sudah menerapkan Kurikulum 2013. Dari hasil observasi yang telah dilakukan, diketahui masih terdapat masalah dalam pelaksaan dari Kurikulum 2013. Berdasarkan observasi tersebut, dapat disimpulkan bahwa masalah yang ada di kelas IV SD Negeri Bergaskidul 03 yang masih berkaitan dengan pelaksanaan Kurikulum 2013, terbagi menjadi dua bagian besar, yaitu masalah yang disebabkan oleh kurang baiknya kinerja guru, serta masalah yang timbul dari aktivitas siswa itu sendiri.

Masalah yang berkaitan dengan kinerja guru, salah satunya dapat dilihat pada penyajian materi. Menurut guru/wali kelas IV SD Negeri Bergaskidul, materi dari tiap mata pelajaran dalam tema terbilang sedikit. Hal ini tentunya membuat guru harus mengembangkan materi sendiri. Sementara itu, pekerjaan guru yang lain masih sangat banyak. Jika semua waktu guru dihabiskan untuk mengembangkan materi maka pekerjaan guru yang lain bisa saja terbengkalai. Tugas-tugas lain seperti kegiatan administrasi kelas dan pengembangan potensi-potensi siswa lainnya menjadi tidak optimal. Bisa dikatakan, muncul kecenderungan bahwa guru "hanya" berkonsentrasi dalam membuat materi ajar, akan tetapi mengesampingkan bagaimana upaya mengajarkannya. Penyebab lain yang masih terkait penyajian materi (kinerja guru), adalah kurang/tidak adanya media yang digunakan guru, padahal media merupakan alat bantu untuk lebih mengoptimalkan proses pembelajaran.

Masalah lainnya, yakni berkenaaan dengan tingkat pemahaman dalam bacaan. Di dalam Kurikulum 2013, semua mata pelajaran terintregasi ke dalam suatu tema. Kurikulum 2013 menuntut siswa untuk memiliki keterampilan membaca yang sangat baik, terutama kemampuan membaca pemahaman. Mata pelajaran yang terintregasi ke dalam sebuah tema membuat batas antara pelajaran satu dengan pelajaran yang lain tidak terlihat. Namun, ketika observasi ke SD Negeri Bergaskidul 03 masih ditemukan siswa yang kebingungan dengan pelajaran yang diintegrasikan dalam sebuah tema. Perubahan struktur materi yang tidak sebiasanya mereka temui, menjadi salah satu penyebab mengapa siswa di SD Negeri Bergaskidul 03 kesulitan memahami materi pembelajaran pada Kurikulum 2013. 
Mei Fita Asri Untari \& Aprilianta Adi Saputra, Keefektifan Media Komik...

Untuk mengatasi masalah kurangnya media dalam pembelajaran Kurikulum 2013 berkenaan dengan membaca pemahaman, guru dapat menggunakan media komik. Komik merupakan cerita bergambar yang disusun secara sistematis dan mempunyai jalan cerita (Maulana, 2008). Komik sangat digemari oleh anakanak pada zaman sekarang. Tidak hanya anak-anak, tetapi juga orang dewasa pun sekarang banyak yang menggemari komik. Salah satu sebab mengapa komik digemari oleh khalayak adalah karena komik mudah dipahami. Untuk membaca komik, dapat dilakukan dengan santai, sesuka hati dan tidak terpaksa. Untuk memahami komik pembaca dapat terbantu dengan gambar yang ada di dalam komik itu sendiri. Keunggulankeunggulan di atas dapat dimanfaatkan untuk pendidikan di sekolah dasar. Siswa yang kurang berminat dalam kegiatan membaca dapat lebih bersemangat untuk membaca ketika melihat bentuk fisik dari komik, dan siswa yang kesulitan dalam memahami sebuah isi bacaan dan terbantu dengan adanya gambar yang ada dalam komik. Berdasarkan alasanalasan di atas, dipilihlah judul "Keefektifan Komik terhadap Kemampuan Membaca Pemahaman pada Siswa Kelas IV SD Negeri Bergaskidul 03 Kabupaten Semarang".

\section{Keterampilan Berbahasa}

Bahasa merupakan alat komunikasi yang digunakan manusia untuk saling berinteraksi dalam kehidupan sehari-hari.
Bahasa bersifat umum, tidak hanya lisan, gestur dan perilaku juga dapat dikelompokkan dalam ragam bahasa. Dalam gestur, seseorang mencoba berkomunikasi melalui mimik wajahnya agar lingkungan sekitar mengerti apa yang dirasakan. Misalnya ketika lelah, maka mimik wajah lesu yang terlihat. Seseorang dikatakan terampil dalam berbahasa apabila menguasai empat keterampilan berbahasa yaitu menyimak, berbicara, membaca dan menulis. Keempat keterampilan tersebut saling terkait dan tidak bisa dipisahkan. Aspek yang satu memerlukan keterlibatan aspek yang lain.

\section{Kemampuan Membaca Pemahaman}

Menurut Lerner (dalam Dalman, 2013), kemampuan membaca merupakan dasar untuk menguasai berbagai bidang studi. Jika anak pada usia sekolah permulaan tidak segera memiliki kemampuan membaca maka ia akan mengalami banyak kesulitan dalam mempelajari berbagai bidang studi pada kelas-kelas berikutnya. Oleh karena itu, anak harus belajar membaca agar ia dapat membaca untuk belajar.

Senada dengan itu, Marcer (dalam Dalman, 2013) menyatakan bahwa kemampuan membaca tidak hanya memungkinkan seseorang meningkatkan kemampuan kerja dan penguasaan berbagai bidang akademik tetapi juga memungkinkan berpartisipasi dalam 
kehidupan sosial, budaya, politik, dan menemukan kebutuhan emosional.

Sebagaimana yang dikemukakan oleh Dalman (2013), bahwa salah satu keterampilan yang harus dimiliki oleh siswa adalah keterampilan membaca pemahaman. Membaca pemahaman adalah membaca yang menitikberatkan pada pemahaman si pembaca. Membaca pemahaman memfokuskan kepada pemahaman si pembaca. Untuk melakukan membaca pemahaman, pembaca haruslah berkonsentrasi. Kosakata yang dikuasai pembaca juga dapat mempengaruhi kualitas membaca pemahaman. Faktor lain yang mempengaruhi membaca pemahaman adalah tingkat intelektual si pembaca. Namun, karena kemampuan membaca pemahaman termasuk sebuah keterampilan, sehingga kemampuan membaca pemahaman pun dapat dilatih, dan faktor yang mempengaruhi kualitasnya, seperti tingkat intelektual pembaca, tentunya dapat diminimalkan.

\section{Media Komik}

Media berasal dari kata Latin 'medius' yang secara harfiah berarti 'tengah', 'perantara' atau 'pengantar'. Gerlach \& Ely (dalam Arsyad, 2013, p. 3) mengatakan bahwa media dapat dipahami secara garis besar adalah manusia, materi, kejadian yang membangun kondisi yang membuat siswa mampu memperoleh pengetahuan, keterampilan, atau sikap. Dalam pengertian ini, guru, buku teks dan lingkungan sekolah merupakan media. Secara lebih khusus, pengertian media dalam proses belajar-mengajar cenderung diartikan sebagai alat-alat grafis, fotografis, atau elektronis untuk menangkap, memproses dan menyusun kembali informasi visual atau verbal (Badruzaman, dkk., 2008).

Hakikat komik, sebagaimana yang dikemukakan oleh Mustikan (2013), adalah perpaduan antara gambar dan bahasa. Ulasan tentang struktur komik tidak bisa dilepaskan dari dua aspek tersebut. Kedua aspek itu saling mengisi, menguatkan dan menjelaskan. Dalam komik pasti ada beberapa adegan yang membutuhkan gambar dengan efek-efek untuk menguatkan dan menjelaskan adegan itu. Misalnya ketika ada adegan orang sedang mengendarai sepeda dengan sangat cepat, pasti adegan ini diberi sebuah efek agar terkesan orang yang dalam gambar tersebut sedang mengendarai sepeda dengan sangat cepat. Berdasarkan aspek visual dan nonvisual tersebut pembaca dapat menafsirkan tokoh yang ada.

\section{METODE}

Penelitian ini menggunakan metode deskriptif kualitatif. Metode deskriptif kualitatif ini merupakan metode yang menggambarkan sebuah peristiwa, benda, dan keadaan dengan sejelasjelasnya tanpa mempengaruhi objek ditelitinya (Soegeng, 2006). Penelitian deskriptif merupakan metode penelitian 
Mei Fita Asri Untari \& Aprilianta Adi Saputra, Keefektifan Media Komik...

yang berusaha menggambarkan dan menginterpretasi objek sesuai dengan apa adanya. Tujuan utama dari penelitian deskriptif kualitatif yaitu menggambarkan secara sistematis fakta dan karakteristik objek atau subjek yang diteliti secara tepat, dan melaporkan keadaan objek atau subjek yang diteliti sesuai dengan apa adanya (Sukardi, 2003). Metode deskriptif kualitatif digunakan agar dapat diketahui keefektifan media komik dalam pembelajaran IV SDN Bergaskidul 03 Kabupaten Semarang.

Selain itu, penelitian ini juga menggunakan desain pre-eksperimental dengan jenis one group pretest posttest design (Sukardi, 2003). Jadi pada penelitian preeksperimen ini, subjek mengalami dua pengukuran. Pengukuran pertama, pengukuran di mana subjek belum dikenai perlakuan berupa pemberian media komik untuk membaca pemahaman. Hasil pengukuran ini dapat dilihat dari hasil pretest para siswa. Pengukuran kedua, pengukuran di mana subjek sudah dikenai perlakuan berupa pemberian media komik terhadap membaca pemahaman. Hasil pengukuran ini dapat dilihat pada hasil posttest para siswa. Dalam praktiknya, digunakan satu kelas sebagai kelompok sampel penelitian. Pemilihan sampel ini berdasarkan pada kelas yang berdistribusi normal.

Dalam penelitian ini, teknik yang digunakan dalam pengambilan data adalah sebagai berikut. a. Metode dokumentasi

Metode dokumentasi adalah mencari data mengenai hal-hal atau variabel yang berupa catatan, transkip, buku, daftar nilai siswa dan sebagainya.

b. Metode tes

Tes adalah serentetan pertanyaan atau latihan serta alat lain yang digunakan untuk mengukur keterampilan, pengetahuan intelegensi, kemampuan/ bakat yang dimiliki oleh individu atau kelompok (Arikunto, 2010, p. 193). Dalam penelitian ini, tes digunakan untuk mengetahui keefektifan pengaruh komik terhadap kemampuan membaca pemahaman pada siswa kelas IV SD Negeri Bergaskidul 03 Kabupaten Semarang.

c. Observasi

Observasi sebagai teknik pengumpulan data mempunyai ciri yang spesifik bila dibandingkan dengan teknik yang lain, yaitu wawancara dan kuesioner. Kalau wawancara dan kuesioner selalu berkomunikasi dengan orang, maka observasi tidak terbatas pada orang tetapi juga objek-objek alam yang lain (Sugiyono, 2010, p. 203). Menurut Sugiyono (2010), observasi merupakan proses yang kompleks, suatu proses yang tersusun dari berbagai proses biologis dan psikologis. Dua di antara yang terpenting adalah proses-proses pengamatan dan ingatan.

\section{Analisis Data}

\section{Analisis awal}

Sebelum dilakukan pengujian hipotesis dengan menggunakan uji beda rata-rata, 
maka terlebih dahulu dilakukan uji normalitas sebagai prasyarat pengujian parametrik (Budiyono, 2009). Secara umum perhitungan uji normalitas data awal dapat diuraikan sebagai berikut.

a. Uji normalitas

Uji normalitas dilakukan dengan tujuan untuk mengetahui normal atau tidaknya data nilai pretest dari kelompok eksperimen. Data berdistribusi normal apabila Lo < Ltabel. Adapun hasil normalitasnya sebagai berikut:

Tabel 1. Uji Normalitas Awal Komik dan Cerita "Meraih Cita Walau Nyaris Putus Asa"

\begin{tabular}{|l|l|}
\hline DATA & $\begin{array}{l}\text { Komik dan Cerita "Meraih } \\
\text { Cita Walau Nyaris Putus Asa" }\end{array}$ \\
\hline Lo & 0,1119 \\
\hline Ltabel & 0,161 \\
\hline
\end{tabular}

Berdasarkan Tabel 1, dengan taraf signifikansi $5 \%$, diperoleh nilai $L_{\circ}=0,1119$ sedangkan Ltabel $=0,161$. Karena $L_{0}<$ Ltabel, maka $H_{\circ}$ diterima sehingga sampel tersebut berdistribusi normal. Sedangkan uji normalitas cerita dan komik "Citacitaku" sebagai berikut:

Tabel 2. Uji Normalitas Awal Komik dan Cerita "Cita-citaku"

\begin{tabular}{|l|l|}
\hline DATA & $\begin{array}{l}\text { Komik dan Cerita "Cita- } \\
\text { citaku" }\end{array}$ \\
\hline Lo & 0,155 \\
\hline Ltabel & 0,161 \\
\hline
\end{tabular}

Berdasarkan Tabel 2, dengan taraf signifikansi $5 \%$, diperoleh nilai $\mathrm{L}_{\mathrm{o}}=0,155$ sedangkan $L_{\text {tabel }}=0,161$. Karena $L_{0}<L_{\text {tabel, }}$ maka $\mathrm{H}_{\circ}$ diterima sehingga data tersebut berdistribusi normal.

\section{Analisis akhir uji normalitas}

Analisis akhir adalah untuk mengetahui normal tidaknya data akhir dari nilai posttest. Data berdistribusi normal apabila Lo < Ltabel.. hasil pengujian normalitas disajikan sebagai berikut ini.

Tabel 3. Uji Normalitas Akhir Komik dan Cerita "Meraih Cita Walau Nyaris Putus Asa"

\begin{tabular}{|l|l|}
\hline DATA & $\begin{array}{l}\text { Komik dan Cerita "Meraih } \\
\text { Cita Walau Nyaris Putus Asa" }\end{array}$ \\
\hline Lo & 0,140 \\
\hline Ltabel & 0,161 \\
\hline
\end{tabular}

Berdasarkan Tabel 3 diperoleh $L_{\circ}=0,140$ pada taraf signifikansi $5 \%$, sedangkan Ltabel $=0,161$. Karena $L_{\circ}<L_{\text {tabel, }}$ maka $\mathrm{H}_{\mathrm{o}}$ diterima sehingga sampel tersebut berdistribusi normal.

Tabel 4. Uji Normalitas Akhir Komik dan Cerita "Cita-citaku"

\begin{tabular}{|l|l|}
\hline DATA & $\begin{array}{l}\text { Komik dan Cerita "Cita- } \\
\text { citaku" }\end{array}$ \\
\hline Lo & 0,150 \\
\hline Ltabel & 0,161 \\
\hline
\end{tabular}

Dengan taraf signifikansi $5 \%$, diketahui dari Tabel 4 bahwa nilai $L_{o}=0,150$ sedangkan Ltabel $=0,161$. Oleh karena Lo $<$ Ltabel, maka $\mathrm{H}_{\circ}$ diterima. Dengan demikian, dapat dikatakan bahwa sampel tersebut memenuhi asumsi normalitas. 
Mei Fita Asri Untari \& Aprilianta Adi Saputra, Keefektifan Media Komik...

\section{HASIL DAN PEMBAHASAN}

Penelitian ini dilakukan di SDN Bergaskidul 03 Kabupaten Semarang. Peneliti memilih kelas IV sebagai sampel dengan siswa 31 orag yang terdiri dari 17 laki-laki dan 14 perempuan. Pada penelitian ini, peneliti menggunakan dua komik dan dua cerita. peneliti menggunakan soal pilihan ganda sebanyak 10 soal untuk masing-masing komik dan 10 soal pilihan ganda untuk masing-masing cerita.

Dalam penelitian ini, digunakan teknik pretest dan posttest. Teknik pretest merupakan teknik pengambilan nilai sebelum dikenai perlakuan. Teknik ini bertujuan untuk mengetahui kemampuan atau hasil awal siswa sebelum diberi perlakuan. Teknik posttest merupakan teknik pengambilan nilai setelah diberi perlakuan. Teknik ini bertujuan untuk mengetahui hasil dari nilai siswa yang sudah diberi perlakuan. Perlakuan dalam penelitian ini berupa pemberian komik sebagai media untuk meningkatkan keterampilan membaca pemahaman.

Pengujian hipotesis pada penelitian ini dilakukan dengan menggunakan uji- $\dagger$ pihak kanan. Adapun data yang diolah adalah nilai angket motivasi belajar dan hasil belajar (pretest dan posttest) kelas eksperimen.

Hipotesis statistik untuk keperluan uji- $\dagger$ adalah sebagai berikut:

$H_{0}: \mu_{1}=\mu_{2}$ (Tidak ada keefektifan media komik terhadap kemampuan membaca pamahaman pada siswa kelas IV SDN Bergaskidul 03 Kabupaten Semarang).

$H_{1}: \mu \neq \mu$ (Ada keefektifan media komik terhadap kemampuan membaca pemahaman pada siswa kelas IV SDN Bergaskidul 03 Kabupaten Semarang).

Kriteria pengujiannya, $\mathrm{H}_{0}$ diterima apabila nilai thitung $<t_{\text {tabel }}$ dengan derajat kebebasan $\mathrm{dk}=\mathrm{n} 1+\mathrm{n} 2$ dengan taraf signifikasi $5 \%$. Untuk harga selain itu, maka $\mathrm{H}_{0}$ ditolak. Setelah dilakukan analisis data nilai hasil belajar cerita "Meraih Cita-cita Walau Nyaris Putus Asa", untuk pretest diperoleh rata-rata 73,33 dan posttest sebesar 81,33. Dengan $n=30, d k=n-1=$ $30-1=29$, diperoleh thitung $=3,878$ pada taraf signifikasi $5 \%$, didapat nilai tabel sebesar 2,048 . Karena thitung $(3,878)>t_{\text {tabel }}$ $(2,048)$ maka hal ini menunjukkan bahwa hasil uji- $\dagger$ hasil belajar adalah signifikan. Dengan kata lain, dapat disimpulkan bahwa terdapat keefektifan media komik terhadap kemampuan membaca pemahaman kelas IV SDN Bergaskidul 03.

Analisis data hasil belajar cerita "Citacitaku" memberikan informasi bahwa dengan rata-rata pretest 53,67 dan posttest 66,67, diperoleh thitung $=2,037$. Sementara berdasarkan tabel distribusi-t, dengan $\mathrm{dk}=\mathrm{n}-1=30-1=29$ (taraf signifikansi $5 \%$ ) didapat nilai tabel $=2,048$. Karena thitung $=2,037>t_{\text {tabel }}=2,048$, maka hal ini menunjukkan hasil signifikan pada uji-† tersebut. Dengan demikian, dapat dikatakan bahwa media komik memiliki pengaruh yang efektif terhadap 
kemampuan membaca pemahaman kelas IV SDN Bergaskidul 03.

Pada penelitian ini, media komik dipilih sebagai alternatif untuk meningkatkan kemampuan membaca pemahaman. Alasan dipilihnya media komik, karena media ini merupakan media visual yang menarik. Dengan gambar berseri yang Iucu dan saling berkaitan, sehingga membentuk suatu cerita yang menarik, membuat siswa merasa tidak jenuh dalam melakukan kegiatan membaca. Oleh karena itu, siswa sangat antusias ketika membaca media komik tersebut.

Peneliti menggunakan dua cerita dan dua komik. Setelah dilakukan penelitian terkumpul data berupa nilai prettest siswa dan posttest siswa. Untuk pengukuran pertama menggunakan cerita "Meraih Cita Walau Nyaris Putus Asa" dari 30 siswa kelas IV SDN Bergaskidul 03 Kabupaten Semarang terdapat 25 siswa dengan kriteria hasil belajar cukup tinggi dan 5 siswa dengan kriteria hasil rendah. Rataratanya adalah 73,33. Setelah diberi perlakuan berupa pemberian komik, dari 30 siswa SDN Bergaskidul 03 Kabupaten Semarang. Diperoleh 29 siswa mencapai nilai dengan kriteria cukup tinggi dan hanya 1 siswa yang masih berkriteria rendah. Rata-rata nilainya naik menjadi 81,33. Persentase kenaikannya adalah $3,878 \%$. Hal ini dikuatkan dengan uji- $\dagger$ cerita dan komik "Meraih Cita Walau Nyaris Putus Asa", bahwa thitung $(3,878)>$ $t_{\text {tabel }}(2,048)$ menunjukkan adanya perbedaan.

Untuk pengukuran kedua dengan menggunakan cerita "Cita-citaku", dari 30 siswa kelas IV SDN Bergaskidul 03 Kabupaten Semarang terdapat 14 siswa dengan kriteria hasil belajar cukup tinggi dan 16 siswa dengan kriteria hasil rendah. Rata-ratanya adalah 53,67. Setelah diberi perlakuan berupa pemberian komik, dari 30 siswa SDN Bergaskidul 03 Kabupaten Semarang. Diperoleh 22 siswa mencapai nilai dengan kriteria cukup tinggi dan 8 siswa yang masih berkriteria rendah. Ratarata nilainya naik menjadi 66,67. Persentase kenaikannya adalah $2.037 \%$. Hal ini dikuatkan dengan uji- $\dagger$ cerita dan komik "Cita-citaku" yang memberikan nilai thitung (6.738) > tabel $(2,048)$ yang menunjukkan adanya perbedaan cukup signifikan. Dengan adanya media komik, siswa menjadi lebih antusias dalam kegiatan membaca. Siswa juga lebih bersemangat ketika membaca komik tersebut. Dengan media komik, siswa yang belum terlalu lancar ketika membaca dapat terbantu dengan adanya gambar berseri di dalam komik tersebut, sehingga dapat terbantu dalam hal memahami cerita. Hal ini jelas sejalan dengan pandangan Slameto (2010), bahwa perubahan kelancaran membaca tersebut menunjukkan adanya perubahan tingkah laku yang menuju pada arah positif, terlihat dari peningkatan nilai dari sebelum dikenai perlakuan dan nilai 
Mei Fita Asri Untari \& Aprilianta Adi Saputra, Keefektifan Media Komik...

setelah diberi perlakuan berupa pemberian komik.

Perbedaan antara hasil belajar berupa mambaca pemahaman sebelum dan sesudah pemberian komik, terjadi karena berbagai faktor yang mempengaruhi. Salah satunya adalah minat dan antusiasme para siswa. Ketika siswa diberikan sebuah cerita, siswa terlihat kurang berminat dan bersemangat. Minat yang dimiliki siswa dapat mempengaruhi hasil belajarnya. Berbeda ketika siswa diberikan sebuah komik. Ketika peneliti memperlihatkan komik kepada siswa. Siswa sangat antusias dan bersemangat. Temuan ini persis seperti hasil kajian Maulana (2008), Maulana (2009), dan Maulana (2010), bahwa penggunaan komik-bahkan untuk pembelajaran sesulit matematika-dapat dijadikan sebagai alternatif yang dapat meningkatkan motivasi belajar siswa secara meyakinkan. Ketika membaca pun, mereka terlihat senang dan tidak jenuh. Media komik dapat memusatkan perhatian para siswa. Kegiatan membaca pemahaman yang mereka lakukan dapat menjadi lebih terfokus. Media komik terbukti efektif untuk kegiatan membaca pemahaman. Hal ini terlihat dari hasil pretest dan posttest mereka. Hasil dari pretest mereka berada di bawah hasil posttest.

Penelitian ini secara keseluruhan hampir sama dengan penelitian yang telah dilakukan oleh Mustikan (2013) yang berjudul penggunaan bahan ajar komik untuk meningkatkan minat belajar IPA SMPN 1 Nalumsari Jepara. Penelitian yang dilakukan Mustikan (2013) adalah penelitian tindakan kelas, yang menginformasikan beberapa hasil, di antaranya bahwa penggunaan bahan ajar berupa komik dapat meningkatkan minat belajar IPA. Hal ini dapat dilihat dari perolehan nilai pada siklus | dan siklus II. Pada siklus 1 diperoleh hasil belajar IPA yang tertinggi adalah 86 sedangkan yang terendah adalah 56 dengan rata-rata 74,80 . Siklus II diperoleh hasil belajar IPA tertinggi adalah 100 sedangkan terendah adalah 64 dan rata-ratanya adalah 80,95.

Setelah dilakukan uji hipotesis, diperoleh simpulan bahwa terdapat keefektifan pengaruh media komik terhadap kegiatan membaca pemahaman pada siswa kelas IV SDN Bergaskidul 03 Kabupaten Semarang.

\section{SIMPULAN}

Berdasarkan hasil penelitian dan pembahasan yang dilakukan, dapat disimpulkan bahwa memang terdapat keefektifan pengaruh media komik terhadap kemampuan membaca pemahaman pada siswa kelas IV SDN Bergaskidul 03 Kabupaten Semarang. Hal ini dapat diperkuat dengan perhitungan parametrik menggunakan uji-t.

\section{REFERENSI}

Arikunto, S. (2010). Prosedur penelitian suatu pendekatan praktik. Jakarta: Rineka Cipta. 
Arsyad, A. (2013). Media pembelajaran. Jakarta: PT Grafindo Prasaja.

Badruzaman, A., dkk. (2008). Media pembelajaran sekolah dasar. Bandung: UPI Bandung PRESS.

Budiyono. (2009). Statistika untuk penelitian. Surakarta: SEBELAS MARET UNIVERSITY PRESS.

Dalman. (2013). Keterampilan membaca. Jakarta: PT Grafindo Prasaja.

Maulana. (2008). Matematikomik sebagai alternatif media dalam pembelajaran matematika untuk meningkatkan motivasi dan prestasi belajar siswa. [Online]. Tersedia: http://file.upi.edu/Direktori/KDSUMEDANG/198001252002121002MAULANA/Artikel/Artikel/Matematikomi k.pdf

Maulana. (2009). Mathematicomic, metaphor, and metacognitive approach in mathematics learning (matematikomik, metafora, dan pendekatan metakognitif dalam pembelajaran matematika). Proceeding of The First International Conference on Basic Education, Indonesia University of Education, Sumedang Campus. ISBN: 97937808-7. [Online]. Tersedia: http://file.upi.edu/Direktori/KDSUMEDANG/198001252002121002MAULANA/Artikel/Artikel/3MMatematikomik-MetakognitifMetafora.pdf

Maulana. (2010). Rapting in doing mathematics, with comics. Proceeding of International Seminar: "Improving the Quality of Elementary Education to Build a Better Future Generation Character", Indonesia University of Education. ISBN: 978-602-98647-0-0. [Online]. Tersedia: http://file.upi.edu/Direktori/KDSUMEDANG/198001252002121002MAULANA/Artikel/Artikel/Rapt\%20in\%20 doing\%20mathematics\%20with\%20comi cs_Seminar_Internasional_Pasca.pdf

Mustikan. (2013). Penggunaan bahan ajar komik untuk meningkatkan minat belajar IPA. Seminar Nasiomal $2^{\text {ndLotar }}$
Physic forum 2013. ISBN:978-602-804780-7. Tersedia: http://prosiding.ikippgrismg.ac.id/index. php/lpf2013/lpf2013/paper/viewFile/115 167.

Slameto. (2010). Belajar dan faktor-faktor yang mempengaruhinya. Jakarta: Rineka Cipta.

Soegeng, A. Y. (2006). Dasar-dasar penelitian bidang sosial, psikologi dan pendidikan. Semarang: IKIP PGRI Semarang PRESS.

Sugiyono. (2010). Statistika untuk penelitian. Bandung: Alfabeta.

Sukardi. (2003). Metodologi penelitian pendidikan kompetensi dan praktiknya. Jakarta: PT Bumi aksara. 